\title{
Radioimmunoassay of serum digoxin in relation to digoxin intoxication
}

\author{
R. B. Singh, A. N. Rai, K. P. Dube, D. K. Srivastav, P. N. Somani, and B. C. Katiyar \\ From the Institute of Medical Sciences, Banaras Hindu University, Varanasi-5, India
}

Serum digoxin estimations were done in 98 patients receiving digoxin for heart failure of varied aetiology. Digoxin toxicity or the lack of it was determined on the basis of established electrocardiographic criteria. Fifty-two patients were classified as 'toxic' and 46 as 'non-toxic'. The difference in the mean digoxin levels between the two groups was highly significant $(P<0.001)$. The mean serum digoxin level in 'non-toxic' patients was slightly higher than that found by other investigators. Fairly good correlations have been noted between different dosage schedules and various rhythm disturbances. Death was attributed to digoxin toxicity in only 2 patients who showed electrocardiographic evidence of intoxication at the time of death.

The therapeutic axiom propounded by William Withering (1937) in $1785^{\prime}$ 'let it be continued until it either acts on to the kidneys, the stomach, the pulse or the bowel' remained the major guideline for a long time regarding the use of digitalis glycosides. However, increasing incidence of digitalis toxicity, rising mortality rate attributed to digoxin, and greater appreciation of its hazards made the development of techniques of estimation of serum digoxin level desirable, in order to allow finer control of doses between the therapeutic and toxic levels.

Doherty, Perkins, and Flanigan (1967) determined myocardial digoxin in animals as well as in man and established a relatively constant ratio with levels in blood. Smith, Butler, and Haber (1969) suggested a sensitive radioimmunoassay for the estimation of blood digoxin levels in non-toxic and toxic patients.

The therapeutic and toxic doses of digoxin are not well delineated and there is great variation in the biological availability of digoxin in tablets prepared by different manufacturers and even in different batches distributed by a single manufacturer. This study was undertaken to determine the serum digoxin levels in patients with digoxin-induced cardiac arrhythmias as compared to those in patients without toxicity. Only those patients who were receiving Lanoxin brand of digoxin from a single batch (Burroughs Wellcome and Co.) have been included in this study.

Received 26 September 1974 .

\section{Subjects and methods}

This prospective study was conducted in the medical wards of the University Hospital, Varanasi, from January 1972 to June 1973 . The criteria for the presence or absence of digoxin intoxication were based upon those accepted by Smith and Haber (1970) and Beller et al. (197I) (Table I).

Clinical, electrocardiographic, and biochemical data were obtained in 98 patients of whom 52 were classified as 'toxic' and 46 as 'non-toxic' (Tables 2 and 3 ).

\section{Serum digoxin estimation}

This was done by radioimmunoassay (Smith et al., 1969). The specificity and sensitivity of this method is excellent and it can detect levels of digoxin well below $0.25 \mathrm{nmol} / \mathrm{l}$ (Butler, 1972).

\section{Blood samples}

The blood samples in the toxic group were taken at the time of electrocardiographic evidence of toxicity, 6 to 24 hours after administration of the previous dose of digoxin. However, in the non-toxic group the samples were collected 7 hours after the administration of the previous dose of digoxin.

Statistical analysis Student's t-test was employed for the analysis of data.

\section{Observations}

\section{Clinical data}

The clinical features of the 52 toxic patients and the 46 non-toxic ones are shown in Table 2. The incidence of predisposing factors was higher in the 
TABLE I Criteria for absence or presence of digoxin intoxication

I) Absence of toxicity (non-toxic group)

Electrocardiographically documented stable sinus rhythm with PR interval of $0.20 \mathrm{~s}$ or less or atrial fibrillation with ventricular response between 70 and IOO beats/min on or off digoxin

2) Presence of toxicity (toxic group)

Complete resolution of any of the arrhythmias given below with discontinuation of digoxin or reduction in dosage of drug, but including two cases who died with persistent arrhythmia.

A) Ectopic ventricular rhythm Multifocal ventricular ectopic beats; unifocal ventricular ectopic beats more than $5 / \mathrm{min}$; ventricular bigeminy or trigeminy or tachycardia

B) Non-paroxysmal AV junctional tachycardia, AV junctional escape rhythm, and AV junctional exit block

C) AV dissociation with ventricular rate exceeding atrial rate

D) Atrial fibrillation with ventricular response less than $50 / \mathrm{min}$ if accompanied by ectopic ventricular beats

E) Sinus rhythm with second or third degree AV block

F) Paroxysmal atrial tachycardia with AV block toxic group than in the non-toxic group. Hypokalaemia was not found as most of the patients were receiving prophylactic potassium chloride $0.5 \mathrm{~g}$ thrice daily in association with diuretic therapy.

\section{Laboratory data}

There was no significant difference in mean serum sodium, potassium, chloride, calcium, and magnesium concentration between the two groups (Table 3). However, the mean blood urea in the non-toxic group was $5.35 \pm 3.4 \mathrm{mmol} / \mathrm{l}$ and in the toxic group it was $7.57 \pm 5.33 \mathrm{mmol} / \mathrm{l}$. The difference was statistically significant $(P<0.01)$.

\section{Serum digoxin levels}

The mean serum digoxin level was higher in the toxic group than in the non-toxic group and the difference was highly significant $(P<0.001)$. However, there was no significant difference in the dosage between the two groups (Table 4).

\section{Dosage forms}

Table 5 reveals that the mean serum digoxin levels in both toxic and non-toxic groups showed an

TABLE 2 Clinical data for 46 non-toxic and 52 toxic patients

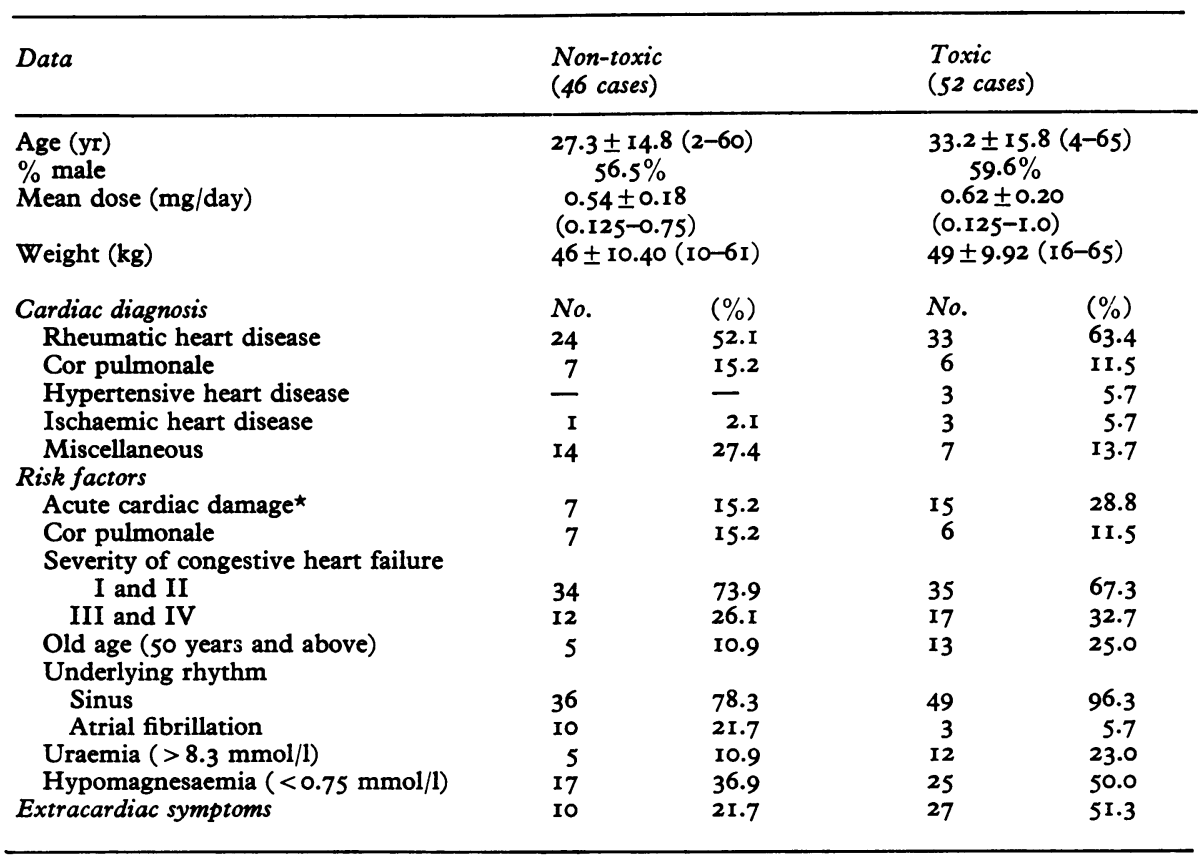

* Acute myocardial infarction, acute myocarditis, subacute bacterial endocarditis, and acute rheumatic carditis.

Conversion factors from SI units to traditional units:

Blood urea: $1 \mathrm{mmol} / \mathrm{l} \approx 6 \mathrm{mg} / \mathrm{dl}$

Serum magnesium: $1 \mathrm{mmol} / 1 \approx 2 \mathrm{mEq} / 1$ 
TA BLE 3 Laboratory data for 46 non-toxic patients and 52 toxic patients

\begin{tabular}{|c|c|c|c|c|}
\hline Data & Normal & Non-toxic & Toxic & $P$ \\
\hline Blood urea (mmol/l) & $3 \cdot 3-6.6$ & $\begin{array}{l}5.3 \pm 3.4 \\
(3.3-22.6)\end{array}$ & $\begin{array}{l}7.6 \pm 5.3 \\
(3.3-23.2)\end{array}$ & $<0.01$ \\
\hline Serum creatinine $(\mu \mathrm{mol} / \mathrm{l})$ & $53.0-106.0$ & $\begin{array}{l}137.0 \pm 174.1 \\
(88.4-910.5)\end{array}$ & $\begin{array}{c}107.8 \pm 42.4 \\
(88.4-309.4)\end{array}$ & NS \\
\hline Serum potassium $(\mathrm{mmol} / \mathrm{l})$ & $3.5-5.0$ & $\begin{array}{l}4.3 \pm 0.53 \\
(3.6-6.0)\end{array}$ & $\begin{array}{l}4.2 \pm 0.40 \\
(3.5-5.0)\end{array}$ & NS \\
\hline Serum magnesium $(\mathrm{mmol} / \mathrm{l})$ & $0.75-1.05$ & $\begin{array}{l}0.76 \pm 0.12 \\
(0.5-1.05)\end{array}$ & $\begin{array}{l}0.73 \pm 0.14 \\
(0.4-1.0)\end{array}$ & NS \\
\hline Serum calcium (mmol/l) & $2.25-2.75$ & $\begin{array}{c}2.5 \pm 0.1 \\
(2.25-2.6)\end{array}$ & $\begin{array}{c}2.4 \pm 0.1 \\
(2.25-2.9)\end{array}$ & NS \\
\hline Serum sodium $(\mathrm{mmol} / \mathrm{l})$ & $120-135$ & $\begin{array}{c}121 \pm 5.88 \\
(105.6-133.3)\end{array}$ & $\begin{array}{l}123 \pm 5.74 \\
(110-134)\end{array}$ & NS \\
\hline Serum chloride (mmol/l) & $85-100$ & $\begin{array}{c}87.5 \pm 5.84 \\
(74.7-102.0)\end{array}$ & $\begin{array}{c}89 \pm 9.60 \\
(63.2-\text { I IO) }\end{array}$ & NS \\
\hline
\end{tabular}

Conversion factors from $S I$ units to traditional units:

Blood urea: $\quad I \mathrm{mmol} / 1 \approx 6 \mathrm{mg} / \mathrm{dl}$

Serum creatinine: $\quad \mathrm{I} \mu \mathrm{mol} / 1 \approx 0.01 \mathrm{mg} / \mathrm{dl}$

Serum magnesium: $1 \mathrm{mmol} / 1 \approx 2 \mathrm{mEq} / 1$

Serum calcium: $\quad I \mathrm{mmol} / \mathrm{l} \approx 4 \mathrm{mg} / \mathrm{dl}$

TABLE 4 Relation between digoxin dosage and mean serum digoxin concentration

\begin{tabular}{|c|c|c|c|}
\hline Data & $\begin{array}{l}\text { Non-toxic } \\
(46 \text { cases })\end{array}$ & $\begin{array}{l}\text { Toxic } \\
\text { (52 cases) }\end{array}$ & $P$ \\
\hline \multicolumn{4}{|c|}{$\begin{array}{l}\text { Serum digoxin level } \\
(\mathrm{nmol} / \mathrm{l})\end{array}$} \\
\hline $\begin{array}{l}\text { Mean } \pm \text { SD } \\
\text { Range }\end{array}$ & $\begin{array}{l}2.91 \pm 1.06 \\
0.77-4.86\end{array}$ & $\begin{array}{l}4.79 \pm 1.72 \\
1.15-13.05\end{array}$ & $<0.001$ \\
\hline \multicolumn{4}{|l|}{$\begin{array}{c}\text { Digoxin dosage } \\
\text { (mg/day) }\end{array}$} \\
\hline Mean \pm SD & $0.54 \pm 0.18$ & $0.62 \pm 0.20$ & NS \\
\hline Range & $0.125-0.75$ & $0.125-1.0$ & \\
\hline
\end{tabular}

Conversion factor from SI unit to traditional unit

Digoxin: $1 \mathrm{nmol} / 1 \approx 0.78 \mathrm{ng} / \mathrm{ml}$.

increase with an increasing dosage of digoxin. The differences in serum digoxin levels between nontoxic and toxic patients with $\mathrm{A}(0.25 \mathrm{mg} /$ day) and $\mathrm{B}$ $(0.5 \mathrm{mg} /$ day) dosage schedules were significant whereas in group C $(0.75 \mathrm{mg} /$ day $)$ they were insignificant. The presence of non-toxic patients with higher mean digoxin levels in group $\mathrm{C}$ could be due to 9 patients with pre-existing atrial fibrillation, who are known to tolerate higher doses of digoxin and higher serum digoxin levels (Smith et al., 1969) without showing any evidence of digoxin toxicity.

\section{Rhythm disturbances}

Serum digoxin levels in relation to various cardiac arrhythmias showed significantly higher levels in patients with second and third degree AV blocks
(5.84 $\pm 2.56 \mathrm{nmol} / 1,3.33-12.93)$ and multifocal ventricular premature beats $(5.33 \pm 2.59 \mathrm{nmol} / 1,2.3-$ 13.06), whereas serum digoxin levels in ventricular bigeminy and trigeminy $(3.89 \pm \mathrm{I} .3 \mathrm{I} \mathrm{nmol} / \mathrm{l}, \mathrm{r} .54-$ 6.78) were not significantly higher than levels in supraventricular arrhythmias (3.37 \pm I.I I nmol/l, I.15-4.35).

In 23 out of 52 cases where serum digoxin levels could be estimated before, during, and after therapy with digoxin, the peak rise of serum level was noted during digoxin toxicity as shown in Table 6.

\section{Mortality}

There were $5(9.6 \%)$ deaths in the toxic group. In 2 $(3.8 \%)$ cases, the death was attributable to digoxin as they showed electrocardiographic evidence of digoxin toxicity at the time of death in the absence of any other obvious cause.

\section{Discussion}

In recent years the incidence of digitalis intoxication has risen considerably and the report that 3 to 39 per cent of deaths in some series may be attributable to digitalis intoxication (Lely and Van Enter, 1972) has brought into question its supremacy in the treatment of congestive heart failure.

Table 4 reveals significantly higher mean serum digoxin level in the toxic group than in the nontoxic group. It is interesting to note that there is no significant difference in the dosage forms between the two groups. The higher level in the toxic 
TABLE 5 Mean serum digoxin concentration in relation to different dosage forms

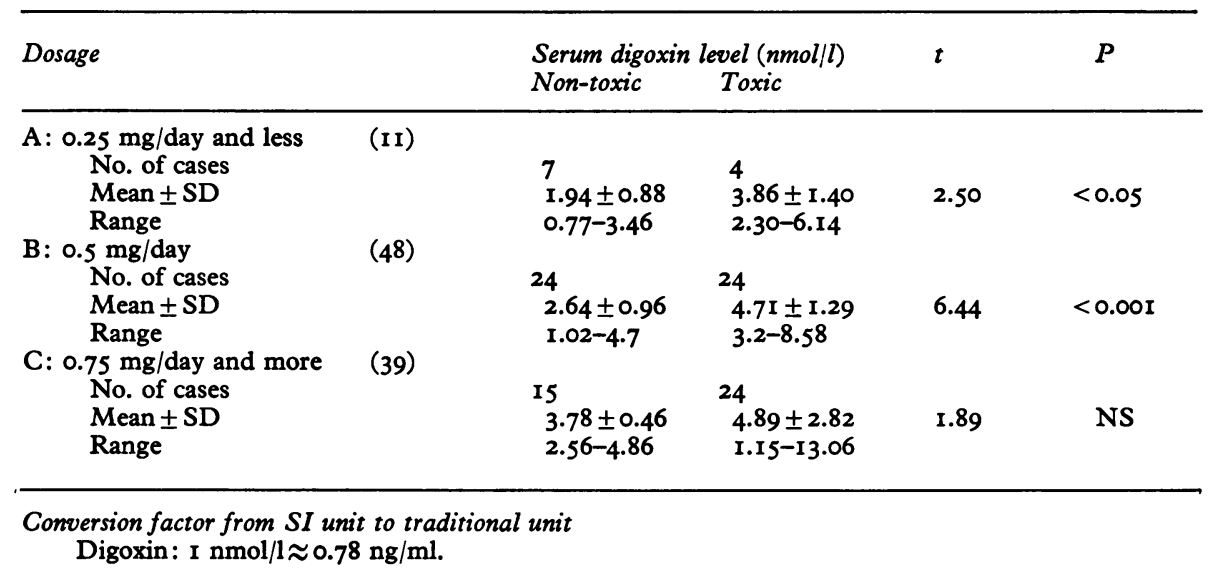

TABLE 6 Serial serum digoxin levels in 23 toxic patients before, during, and after treatment of digoxin toxicity

\begin{tabular}{|c|c|c|c|}
\hline Data & $\begin{array}{l}\text { Before } \\
\text { toxicity }\end{array}$ & $\begin{array}{l}\text { During } \\
\text { toxicity }\end{array}$ & $\begin{array}{l}\text { After } \\
\text { treatment of } \\
\text { toxicity }\end{array}$ \\
\hline $\begin{array}{l}\text { Mean (nmol/l) } \\
\text { Range }\end{array}$ & $\begin{array}{l}2.76 \\
1.15-4.09\end{array}$ & $\begin{array}{l}4.95 \\
2.30-12.93\end{array}$ & $\begin{array}{l}2.46 \\
0.64-4.09\end{array}$ \\
\hline
\end{tabular}

Conversion factor from SI unit to traditional unit

Digoxin: $1 \mathrm{nmol} / 1 \approx 0.78 \mathrm{ng} / \mathrm{ml}$.

group may be attributed to impaired renal functions (Table 3).

It is apparent from various studies that serum digoxin concentrations in non-toxic patients usually lie in the $0.64-2.56 \mathrm{nmol} / \mathrm{l}$ range but that a significant number have serum concentrations in excess of $2.56 \mathrm{nmol} / 1$. However, in a majority of patients with definite digoxin-induced cardiac arrhythmias serum concentrations were noted in the 1.79$5.12 \mathrm{nmol} / \mathrm{l}$ range (Butler, 1972). In this study, the mean serum digoxin level in non-toxic patients was $2.92 \pm 1.06 \mathrm{nmol} / 1$ which is slightly higher than the values reported by Smith et al. (1969), Smith and Haber (1970), and Beller et al. (1971) but closer to the levels reported by Evered, Chapman, and Hayter (1970).

The cause of this difference is not clear as there are no other serum digoxin studies in an Indian population, as far as we know. A possible explanation for this discrepancy, therefore, could be the short stature and lower mean body weight $(46 \pm$ ro.4 $\mathrm{kg}$ in non-toxic group), but similar mean daily dose $(0.54 \pm 0.1 \mathrm{mg} /$ day), of the patients in this series. It is also likely that the biological availability of digoxin in tablets used by us was higher as compared to other workers.

Further factors that may be involved arise from the fact that the rise in serum concentration after administration of digoxin is dependent upon the route of administration, and individual variations in absorption, distribution, and elimination.

There is good correlation between daily maintenance digoxin dosage and serum concentration of the drug as observed in this study (Table 5). This relation was fairly good when the patients were given $0.25 \mathrm{mg} /$ day and $0.5 \mathrm{mg} /$ day of digoxin in the non-toxic group of patients. However, when the patients were given $0.75 \mathrm{mg} /$ day of drug daily, the difference between serum digoxin levels of nontoxic and toxic patients was insignificant. This was also observed by other investigators (Smith et al., 1969; Smith and Haber, 1970; Evered et al., 1970).

Smith and Haber (1970) noted fairly good correlation between serum digoxin levels and various categories of arrhythmias, and they found significantly higher levels in patients who had supraventricular tachycardia with block or ventricular arrhythmias, than in patients who had atrial fibrillation with ventricular premature beats or second or third degree AV block. Further they pointed out that in cases with organic disease of the conducting system even low digoxin levels might precipitate significant AV block while in patients with supraventricular tachyarrhythmias higher levels may be required to control the ventricular rate.

Our results conflict with the observations of Smith and Haber (1970) as we found higher levels in patients with second or third degree AV block or ventricular arrhythmias and lower levels in 
patients with supraventricular arrhythmias. The production of supraventricular arrhythmias at lower levels of digoxin may be due to pre-existing increased conductivity of cardiac muscle as a result of advanced heart disease, especially when the atria are enlarged because of rheumatic mitral heart disease. In such patients low levels of digoxin may be enough to produce atrial arrhythmias. Thus, it appears that particular serum digoxin levels as such do not determine the type of arrhythmia. It is the pre-existing heart disease either affecting the conduction system or atria, which predisposes the patients and determines the type of arrhythmia at a relatively lower level of digoxin. However, ventricular arrhythmias, especially multifocal ventricular premature beats as observed by us, may require higher levels of digoxin for their manifestation in the absence of significant heart disease. Thus, it should be emphasized that the total clinical picture has to be considered in association with the serum digoxin level to reach a definite conclusion whether a particular cardiac arrhythmia is digoxin induced.

In 23 toxic patients in which serum digoxin levels were estimated before, during, and after toxicity, the highest mean digoxin level was observed during toxicity. This shows that comparatively higher serum drug levels are essential to produce digoxin toxicity, as it disappears with the diminution in the serum digoxin level (Table 6).

We did not observe a sharp line of demarcation in the serum digoxin levels between the two groups as there was considerable overlap. The range of serum digoxin level in the non-toxic group was $0.77-4.87 \mathrm{nmol} / \mathrm{l}$ whereas in the toxic group it ranged from 1.15-13.06 nmol/1. However, there were 16 cases in the toxic group with serum digoxin levels of more than $5.12 \mathrm{nmol} / \mathrm{l}$. There were only 4 patients in the toxic group who had levels below $2.56 \mathrm{nmol} / 1$ but $2 \mathrm{I}$ in the non-toxic group. Maximum overlapping therefore was seen in the range of $2.56-5.12 \mathrm{nmol} / 1$.

In 2 patients ( $3.8 \%$ ) of the toxic group death was attributable to digoxin. One had ventricular tachycardia and the other multifocal premature beats. The incidence of death as a direct result of digitalis intoxication in different studies ranges from 3 to 21 per cent (Rodensky and Wasserman, I96I, Schott, 1964; Beller et al., 1971; Agarwal and Agarwal, 1972).

Thus, it appears that there is great variability in serum levels of digoxin and its toxic manifestations. However, if other clinical as well as electrocardiographic manifestations are correlated with the serum digoxin levels, the diagnosis of presence or absence of digitalis intoxication becomes clearer.

Our thanks are due to Padamashree Professor, K. N. Udupa Director, for permission to publish this article.

\section{References}

Agarwal, B. L., and Agarwal, B. V. (1972). Digitalis intoxication in hospital practice. Fournal of the Indian Medical Association, 58, I64.

Beller, G. A., Smith, T. W., Abelmann, W. H., Haber, E., and Hood, W. B. (197I). Digitalis intoxication: a prospective clinical study with serum level correlations. New England fournal of Medicine, 284, 989.

Butler, V. P., Jr. (1972). Assays of digitalis in the blood. Progress in Cardiovascular Diseases, 14, 571.

Doherty, J. E., Perkins, W. H., and Flanigan, W. J. (1967). The distribution and concentration of tritiated digoxin in human tissues. Annals of Internal Medicine, 66, I 6.

Evered, D. C., Chapman, C., and Hayter, C. J. (1970). Measurement of plasma digoxin concentration by radioimmunoassay. British Medical fournal, 3, 427.

Lely, A. H., and Van Enter, C. H. J. (1972). Editorial. Noncardiac symptoms of digitalis intoxication. American Heart fournal, 83, 149.

Rodensky, P. L., and Wasserman, F. (196I). Observations on digitalis intoxication. Archives of Internal Medicine, ro8, I7I.

Schott, A. (1964). Observation on digitalis intoxication - a plea. Postgraduate Medical fournal, 40, 628.

Smith, T. W., Butler, V. P., Jr., and Haber, E. (1969). Determination of therapeutic and toxic serum digoxin concentrations by radioimmunoassay. New England fournal of Medicine, 281, 1212.

Smith, T. W., and Haber, E. (1970). Digoxin intoxication: the relationship of clinical presentation to serum digoxin concentration. Fournal of Clinical Investigation, 49, 2377.

Withering, W. (1937). An account of Foxglove and some of its medical uses: with practical remarks on dropsy and other diseases. Robinson, Birmingham, England, I785. Reprinted in Medical Classics, 2, 305.

Requests for reprints to Professor B. C. Katiyar, Department of Medicine, Institute of Medical Sciences, B.H.U. Varanasi-5, India. 